\title{
砂の平面ひずみ挙動に及ぼす 初期応力状態の影響
}

\author{
徳江俊秀 1 釜井俊孝 ${ }^{2} \cdot$ 梅津喜美夫 ${ }^{3}$ \\ ${ }^{1}$ 正会員 工博 日本大学教授 理工学部土木工学科（采101-8308 東京都千代田区神田駿河台1-8）

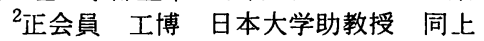 \\ 3正会員 工博 日本大学尃任講師 同上
}

\begin{abstract}
本研究は，従来あまり意識されていなかった平面ひずみ試験の初期応力状態に着目し，豊浦砂の直方体 供試体（寸法 $9 \times 8 \times 5 \mathrm{~cm}$ ）を用いてその影響について調べてみたものである．平面ひずみ圧縮試験（CD試 験, $\sigma_{\mathrm{x}}=\sigma_{\mathrm{x} 0}=$ 一定）の初期応力状態は, $100 \leqq \sigma_{x 0} \leqq 300,25 \leqq \sigma_{50} \leqq 500, \sigma_{\mathrm{x} 0}=100$ (単位: $\mathrm{kN} / \mathrm{m}^{2}$ ) の範 囲で種々設定した. その結果以下の様な結論が得られた. (1)初期応力状態は，その載荷中の体積变化特性 に着目することにより 3 つのパターンに分けられる. (2)平面ひずみ圧縮試験中の応力経路は, 上記のパター

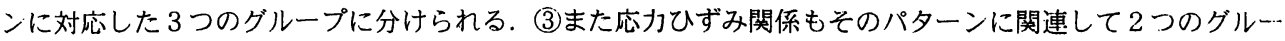
プに分けられる. (4)しかしながら強度は初期応力の影響を受けず一定の大きさを示す.
\end{abstract}

Key Words : plane strain compression test, initial stress condition, induced anisotropy, dilatancy, stress strain relation, stress path, shear strength, sand

\section{1 . はじめに}

堤体やロックフィルダムまたは長い帯基礎下の地 盤など, 建設工事の対象となる多くの土構造物や地 盤は, 一方向の変形が拘束される状況にあるため平 面ひずみ状態と考えられる. 実際の地盤をこのよう に 2 次元問題として扱うと, F E M 等による電算機 を用いた解析が容易になるというメリットがある.上, 一般的に平面ひずみ条件下の強度・変形特性は, 常 用されている軸対称の三軸試験によるものに比べ, 設計に有利な結果を示す。土木工事は大規模で莫大 な土工量を伴う場合が多いが, このような場合，上 述のような平面ひずみ試験から，現実の状態に近 く，しかも設計に有利な定数を得て安定解析を行い 設計がなされれば, 巨額の工事費の削減につながる. このようなことから平面ひずみ条件下の土の特性を 調べる研究が重要視され，今日まで様々な研究がな されてきている.

しかしながら，このような平面ひずみ状態にある とされている実際の地盤の状況を考えると, 土質の 不均一性, 作用荷重分布の非一椂性等から, 現䒠に は地盤内の土要素が完全な平面ひずみ状態, すなわ ち，側方拘束ひずみがゼロという状態にあるとは考
えにくい，そこで既報 ${ }^{1)}$ では，本来ゼロの側方ひず みを微小な範囲で許していった時, 土における平面 ひずみ条件として許容できる限界側方ひずみについ ての検討を行ない，更にこの限界側方ひずみより大 きな側方ひずみの発生を許していったとき，その滛 の平面ひずみ挙動にこの発生ひずみがどう影響する かについて述べた.

また一方，平面ひずみ状態にあるとされている地 中の実際の寸:要素を考えると, 周辺の建造物の影響 や掘削, 盛土等の工事過程で様々な外力を受け, 多 様な応力状態を示していると考えられる。しかしな がら, 従来行なわれている平面ひずみ状態の土の研 究において, 平面ひずみ圧縮の直前における初期応 力状態についてはほとんど意識されておらず, 主に, (1)左右の側方拘束板をロッドで固定し, 側方変位が 発生し得ない状態で供試体を作製し，そのまま压密

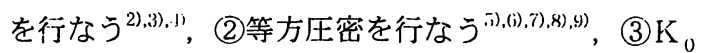
圧密を行なら(0),11),12),13),1-1),(5),16)，などの限られた方 法でしか初期応力状態を作り出していない，実際の 地盤は先にも述べたように，多様な応力状態を示す ことが考えられるわけであり，このような戦純な状 態ではない. そこで本研究は, 従来あまり意職され ていなかった初期応力状態に着目し, 豊浦砂の供試 


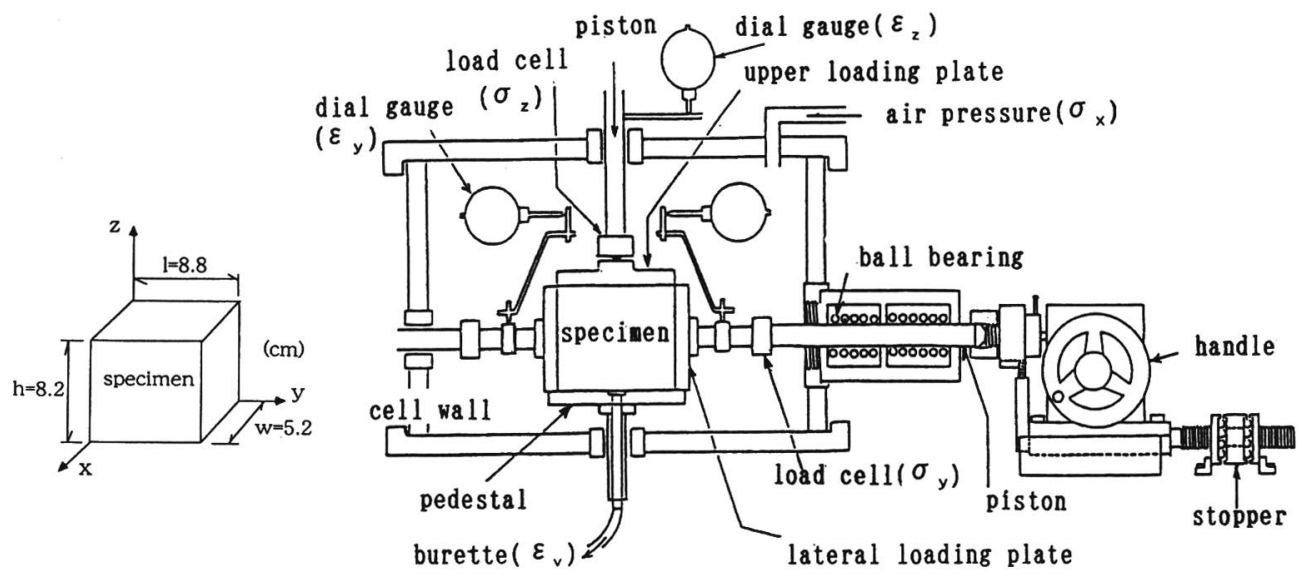

図-1 セル断面と側方変位（応力）調整装置

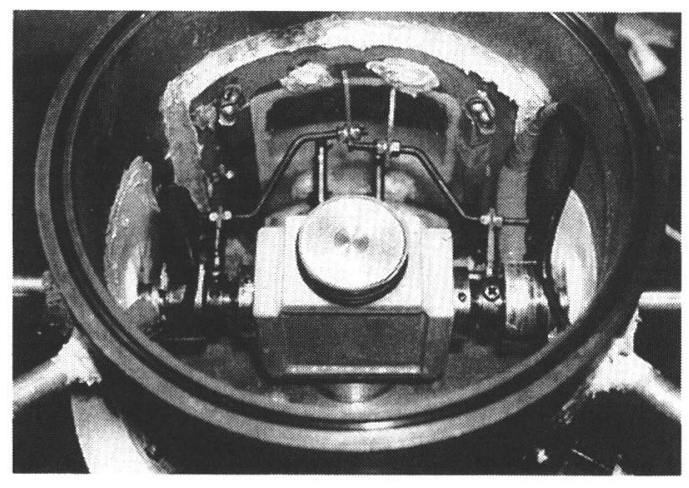

写真- 1 セル内の供試体

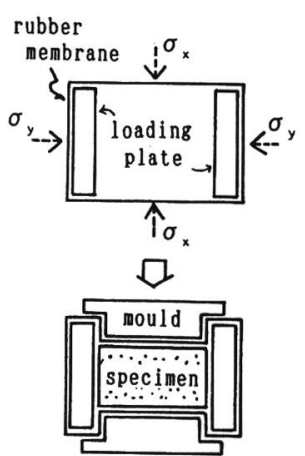

図-2 供試体の作製 $\left(\sigma_{\%}\right.$ 方向)
体について，平面ひずみ挙動に及ぼす様々な初期応 力状態の影響について調べてみた.

\section{2. 装置と試験方法}

\section{（1）試験装置}

装置のセル断面を図- 1 に示す. 主応力について は， $\sigma_{z}, \sigma_{y}$ はピストンを介して剛板（寸法： $\sigma_{\%}$, $\sigma_{y}$ 両方向共 $\left.8 \times 6 \mathrm{~cm}\right)$ で載荷され， $\sigma_{x}$ はセル内の 空気圧によって載荷される。 $\sigma$, 載渮は荷重制御・ 変位制御が共に可能であが， $\sigma_{\mathrm{y}}$ の載荷は，図-1に 示すような側方変位調整装置のハンドルによって行 なう.このハンドルは, 60回転で側方変位が $1 \mathrm{~mm}$ （圧縮・引張両方向共）調整できる. また， $\sigma_{z}, \sigma_{v}$ および $\sigma_{x}$ の載荷システムはそれぞれ独立であるた め, 任意の応力径路で載荷できる.
主応力の測定は， $\sigma_{z}, \sigma_{y}$ はロードセルで， $\sigma_{x}$ は プレッシャーゲージによってなされる.なお，ロ… ドセルはセル内にセットされているため, ビストン とセル壁の間に働く摩擦は軸応力 $\sigma \%, \sigma, に$ 影響し ない.これらの計器の性能は以下の通りである. $\sigma$ ，方向ロードセル：定格容量, $9.8 \mathrm{kN}$. 最小読み 取り值， $2.45 \mathrm{~N}$ (応力にすると $0.54 \mathrm{kN} / \mathrm{m}^{2}$ ) $\sigma_{y}$ 方向ロードセル：定格容量, $4.9 \mathrm{kN}$. 最小読み 取り値, $1.67 \mathrm{~N}$ (応力にすると $0.39 \mathrm{kN} / \mathrm{m}^{2}$ ) プレッシャーゲージ：最大測定値, $588 \mathrm{kN} / \mathrm{m}^{2}$. 最小目盛り, $1.96 \mathrm{~N} / \mathrm{m}^{2}$.

主ひずみについては， $\varepsilon$ \&図-1に示すように， セル上部にセットされた $1 / 100 \mathrm{~mm}$ 精度のダイヤル ゲージで測定され， $\varepsilon_{y}$ はセル内にセットされた 1/1000mm精度のダイヤルゲージによって制定さ

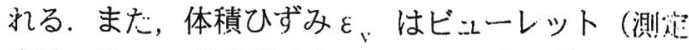
容量： $50 \mathrm{cc}$ ，最小目盛り：0.1cc(体積ひずみにずる 
0 : inisial stress state

$$
\left(\sigma_{\mathrm{xo}}=100 \mathrm{kN} / \mathrm{m}^{2}\right)
$$

$$
\sigma_{\mathrm{zo}}\left(\mathrm{kN} / \mathrm{m}^{2}\right) \quad \rightarrow \text { : roading process }
$$

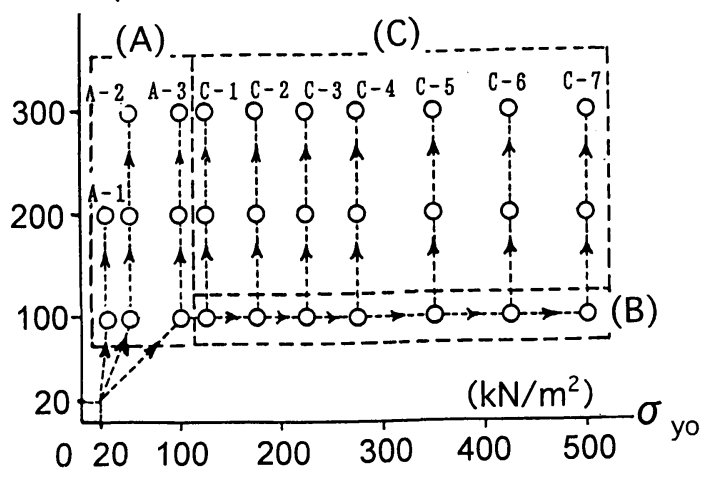

図-3 初期応力状態とその達成経路
表-1 初期応力状態の種類

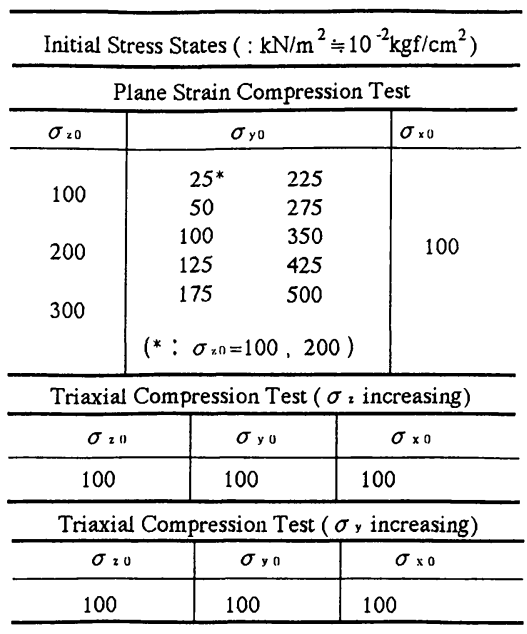

と約0.027\%)）によって測定される.

\section{（2）試料および供試体}

\section{a) 試料}

試験に用いた試料は豊浦砂で，比重は $\mathrm{G}_{\mathrm{s}}=2.64$ である.また, $50 \%$ 粒径は $\mathrm{D}_{50}=0.172 \mathrm{~mm}$ であり, 均等係数は $\mathrm{U}_{\mathrm{c}}=1.32$ である.

\section{b ) 供試体}

セル内の供試体の状況を写真- 1 に示す。供試体 を被うゴムスリーブ（厚さ $0.4 \mathrm{~mm}$ ）の形状は矩形 で, 左右の $\sigma_{y}$ 載荷板を外側で被っているため, 拘 束方向の応力 $\sigma_{y}$ はセル压 $\sigma_{x}$ より小さくできる. ま た，供試体と上下，左右の載荷板との間に働く摩擦 は, 既報 ${ }^{1)}$ と同栐, 適切な量のシリコングリースを 塗布した愿さ $0.05 \mathrm{~mm}$ のテフロンシートと厚さ $0.2 \mathrm{~mm}$ のゴムシートを用いて軽減してある.

供試体の作製方法は，図一 2 に示すように， $\sigma_{x}$ (空気圧)載荷面のゴムスリーブに凸型のモ一ルドを 設置し，その中に飽和砂を10層に分けて投入し，各 層毎に突き棒で100回ずつ突き詰めて作製した.こ のモールドは供試体を密閉した後, $20 \mathrm{kN} / \mathrm{m}^{2}$ の負 圧下で取りはずされる。この時の供試体の寸法は, 図ー1に示すように長さ $8.8 \mathrm{~cm} \times$ 高さ $8.2 \mathrm{~cm} \times$ 幅 $5.2 \mathrm{~cm}$ であり，間げき比は $\mathrm{e}_{0}=0.578 \sim 0.630$ であ る.

\section{（3）試験方法}

供試体の作製完了時点には, $\sigma_{z}=\sigma_{\mathrm{y}}=\sigma_{\mathrm{x}}=$ $20 \mathrm{kN} / \mathrm{m}^{2}$ の等方応力状態であり, ここから様々な 応力状態を作りだした後, 平面ひずみ条件に切り替 え, 軸応力 $\sigma_{z}$ を増加させて供試体を破壊させた。
以下, 前者の過程を「初期応力達成過程」, 後者の 過程を「平面ひずみ圧縮過程」と呼ぶ.これらの過 程の詳細は次の通りである.

\section{a) 初期応力達成過程}

初期応力状態は, 図-3に示すように，まず $\sigma_{z}=$ $\sigma_{y}=\sigma_{x}=20 \mathrm{kN} / \mathrm{m}^{2}$ の供試体作製完了時点（等方応 力状態）から, 図に示すような $\rightarrow$ 載荷径路に沿つ て圧縮し, 所定の初期応力状態 (○印) を達成した. 初期応力達成時点の $\sigma_{x 0}$ は、どの供試体も全て $100 \mathrm{kN} / \mathrm{m}^{2}$ となっている. この図からわかるように, 初期応力状態が $\sigma_{\mathrm{y} 0} \geqq \sigma_{\mathrm{x} 0}=100 \mathrm{kN} / \mathrm{m}^{2}$ の場合, すなわち， $\mathrm{A}-3$ 径路と C, Bの範囲のものは, 20 $\mathrm{kN} / \mathrm{m}^{2}$ の等方状態から, 更に等方載荷されて $\sigma_{z}=$ $\sigma_{\mathrm{y}}=\sigma_{\mathrm{x}}=100 \mathrm{kN} / \mathrm{m}^{2}$ の応力状態を経て, 所定の初 期応力状態になっている. また, 初期応力が $\sigma_{y_{0}}<$ $\sigma_{x 0}=100 \mathrm{kN} / \mathrm{m}^{2}$ の場合, すなわち, $\mathrm{A}-1, \mathrm{~A}-2$ 径路のものは, $20 \mathrm{kN} / \mathrm{m}^{2}$ の等方状態から異方載荷 $\left(\sigma_{z}=\sigma_{x}>\sigma_{y}\right)$ されて $\sigma_{z}=\sigma_{x}=100 \mathrm{kN} / \mathrm{m}^{2}$ の応力 状態を経て, 所定の初期応力状態になっている.こ こで, A- 1 径路をたどる初期応力状態で $\sigma_{20}=$ $300 \mathrm{kN} / \mathrm{m}^{2}$ のものがないのは, 達成過程で供試体が 破壊したために設定できなかったからである.なお, 所定の初期応力状態の達成後, 30 分間この応力を 載荷し続け, 応力が確実に伝達されるようはかった.

表- 1 は, このようにして設定した初期応力状態 の種類を示している. 試験はそれぞれの種類につい て $2 \sim 3$ 回実施し, ほぼ同様の結果が得られること を確認し, 各種類の結果はそれらの平均した值を示 している. 平均の方法については, 応力ひずみ関係 については，同一の軸ひずみ $\varepsilon_{z}$ に対して軸差応力 $\left(\sigma_{\%}-\sigma_{x}\right)$ および体積ひずみ $\varepsilon_{v}$ を平均し，また， 


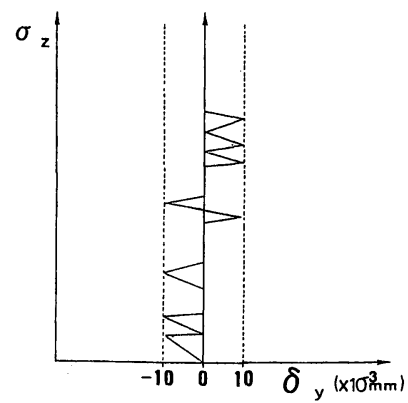

図-4 側方変位の調整

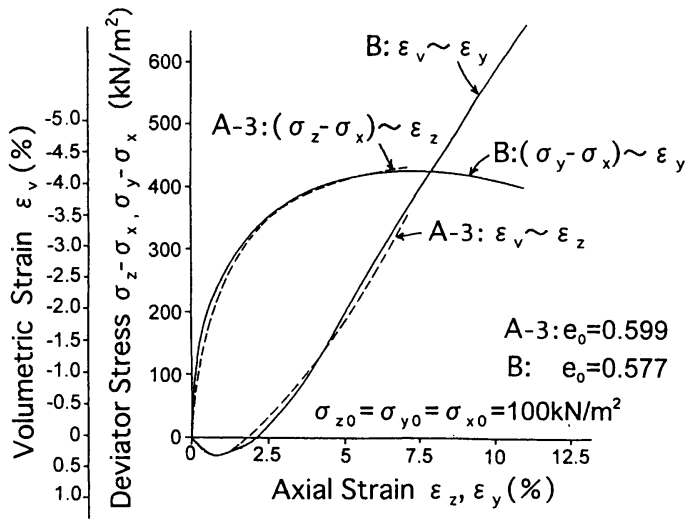

図-5 載荷方向の違いによる変形挙動の比較

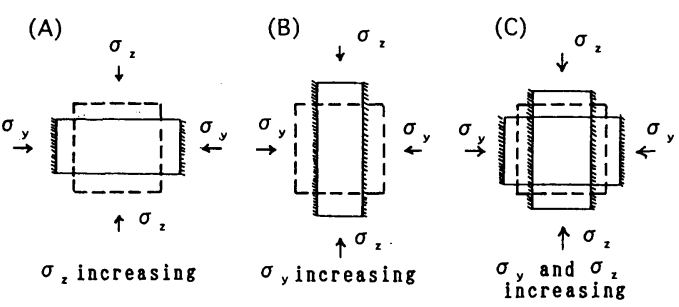

図-6 初期伈力達成過程の供試体の変形パターン

応力径路については, 同一の $\sigma_{z} / \sigma_{x}$ に対して $\sigma_{y} /$ $\sigma_{x}$ を平均している. なお, 表に示してある $\sigma_{y}$ 方向 圧縮の三軸試験は, 初期応力 $\sigma_{y_{0}}$ の載荷による供試 体の変形をあらかじめ把握しておくために行った予 備的な試験である.

\section{b ）平面ひずみ圧縮過程}

初期応力達成後の供試体の平面ひずみ圧縮（ $\sigma$ z 方向の圧縮）は， $\sigma_{y}$ 方向の変位を拘束し, $\sigma_{x}=$ $100 \mathrm{kN} / \mathrm{m}^{2}=$ 一定にして, 排水条件で行った. 載荷 方法については，応力制御で行った。平面ひずみ圧 縮中の，ロードセル等の軸変位によって生じる左右 それぞれの側方変位は，図-4に示すように，膨張
側も収縮側も $\left.10 / 1000 \mathrm{~mm} （ \varepsilon_{y} \fallingdotseq 0.01 \%\right)$ の幅で 制御を行い, 平面ひずみ状態を維持した.

\section{3. 試験結果と考察}

\section{（1）供試体の初期構造特性}

まず，図-5の応力ひずみ関係は， $\sigma_{2,0}=\sigma_{y, 0}=$ $\sigma_{\mathrm{x} 0}=100 \mathrm{kN} / \mathrm{m}^{2}$ の等方初期応力状態から， $\sigma_{\%}$ 方 向に圧縮していった場合 $\left(\mathrm{A}-3:\left(\sigma_{2}-\sigma_{x}\right) \sim \varepsilon\right.$ ，関 係）と， $\sigma_{y}$ 方向に圧縮していった場合（B:( $\sigma_{y},-$

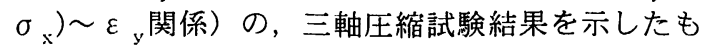
のである.これらの載荷径路は，それぞれ図ー 3 に 示した $\mathrm{A}-3$ の径路および $\mathrm{B}$ の径路と同じである. この図により, 両者の応力ひずみ関係を比較すると, $\mathrm{A}-3$ と B とでは, 間げき比が 0.02 ほど異なるが, ほぼ同じような応力ひずみ関係になっていることが 認められる.このことから，本実験の供試体作製方 法で得られた供試体の初期構造は等方的であること がわかる.なお，図ー3のB 径路上にある $\sigma_{y 0}=$ $500 \mathrm{kN} / \mathrm{m}^{2}$ の初期応力状態は, 軸差応力に直すと $\left(\sigma_{\mathrm{y}}-\sigma_{\mathrm{x}}\right)=400 \mathrm{kN} / \mathrm{m}^{2}$ となり，破壊 $\left(\left(\sigma_{\mathrm{y}}-\sigma_{\mathrm{x}}\right)_{\mathrm{f}} \doteqdot\right.$ $\left.430 \mathrm{kN} / \mathrm{m}^{2}\right)$ 近くの状態を表していることがわかる.

\section{（2）初期応力達成過程}

\section{a ) 供試体の変形パターン}

実施した初期応力状態およびその達成径路を図一 3 に示したが, 初期応力達成過程の供試体の変形を 分類すると, 概ね図-6 のように(A),(B),(C)の 3 つに分けることができる. (A),(B),(C)の各図は, 図ー3に示した記号と対応している。 すなわち, (A)は $\sigma_{z}$ が単調載荷されて, 供試体の変形が横長に なる応力状態であり，(B)は $\sigma_{\mathrm{y}}$ が単調載荷されて, 縦長になる応力状態であり，Cは $\sigma_{\mathrm{y}}$ がまず載荷さ れ, その後 $\sigma_{z}$ が載荷（複合載荷）される場合で, 両応力の大きさによって横長になったり縦長になっ たりする応力状態である（( A )と（B)の複合状 態).

\section{b ）体積変化特性}

次に, 初期応力達成過程の体積変化特性を上記の (A),(B),(C)の代表例について示したものが図-7 (A),(B),(C)である.すなわち, (A),(B),(C)の各 図は図-6 $6(A),(B),(C)$ と対応し，また，図中の 記号（A-1など）は図-3の記号と対応している. 図-7の(A),(B),(C)のそれぞれの場合の載荷径路 とそれらの体積変化特性について以下に述べる,

A ((A)図)：載荷径路が $\sigma_{z}<100 \mathrm{kN} / \mathrm{m}^{2}$ の過程で は, A-1, A-2 各径路とも $\sigma_{z}=\sigma_{x}$ の状態で応力が 

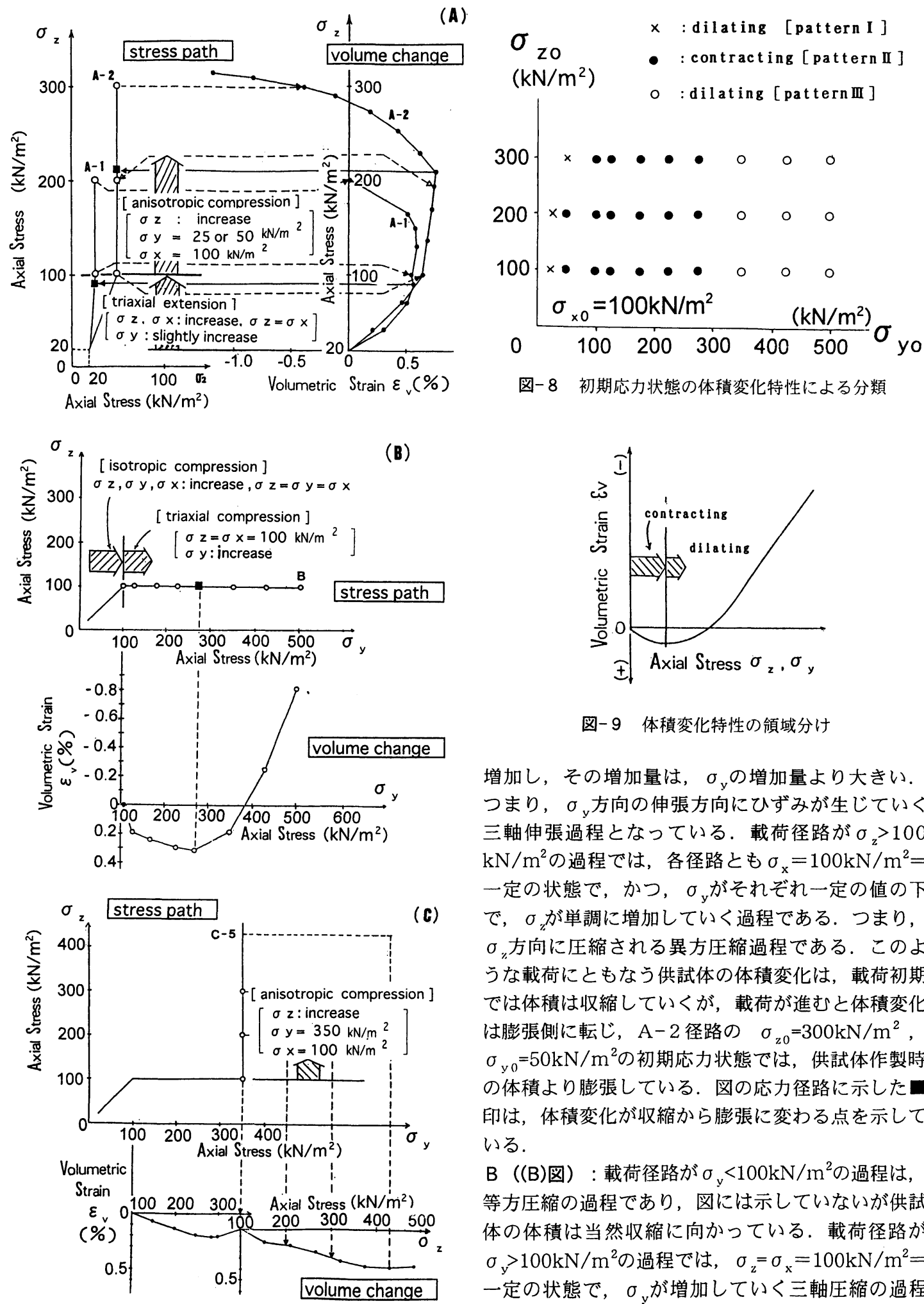

図-8 初期応力状態の体積変化特性による分類

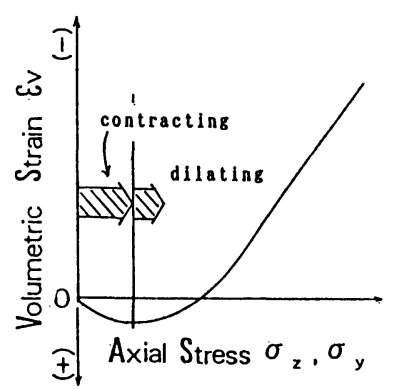

図-9 体積変化特性の領域分け

增加し, その増加量は, $\sigma_{\mathrm{y}}$ の増加量より大きい.

つまり， $\sigma_{\mathrm{y}}$ 方向の伸張方向にひずみが生じていく 三軸伸張過程となっている. 載荷径路が $\sigma_{z}>100$ $\mathrm{kN} / \mathrm{m}^{2}$ の過程では, 各径路とも $\sigma_{\mathrm{x}}=100 \mathrm{kN} / \mathrm{m}^{2}=$ 一定の状態で, かつ， $\sigma_{\mathrm{y}}$ がそれぞれ一定の值の下 で， $\sigma_{z}$ が単調に増加していく過程である.つまり, 。,方向に圧縮される異方圧縮過程である. このよ うな載荷にともなう供試体の体積変化は, 載荷初期 では体積は収縮していくが, 載荷が進むと体積変化 は膨張側に転じ, $\mathrm{A}-2$ 径路の $\sigma_{z 0}=300 \mathrm{kN} / \mathrm{m}^{2}$, $\sigma_{\mathrm{y} 0}=50 \mathrm{kN} / \mathrm{m}^{2}$ の初期応力状態では, 供試体作製時 の体積より膨張している. 図の応力径路に示した 印は，体積変化が収縮から膨張に変わる点を示して いる.

B ((B)図)：載荷径路が $\sigma_{\mathrm{y}}<100 \mathrm{kN} / \mathrm{m}^{2}$ の過程は, 等方圧縮の過程であり, 図には示していないが供試 体の体積は当然収縮に向かっている. 載荷径路が $\sigma_{\mathrm{y}}>100 \mathrm{kN} / \mathrm{m}^{2}$ の過程では, $\sigma_{z}=\sigma_{\mathrm{x}}=100 \mathrm{kN} / \mathrm{m}^{2}=$ 一定の状態で， $\sigma_{\mathrm{y}}$ が増加していく三軸圧縮の過程 になっている.この径路の供試体の体積は， $\sigma_{\mathrm{y}}=$ $280 \mathrm{kN} / \mathrm{m}^{2}$ 付近（回印）を境に膨張するのが認めら れる. 


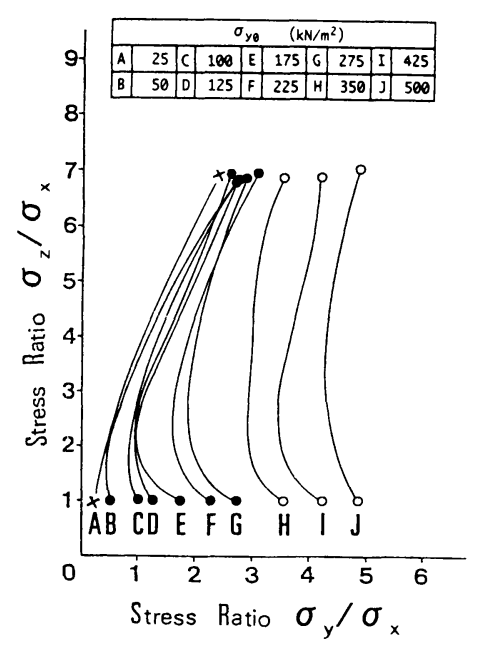

(1) $\sigma \%=100 \mathrm{kN} / \mathrm{m}^{2}$ の場合

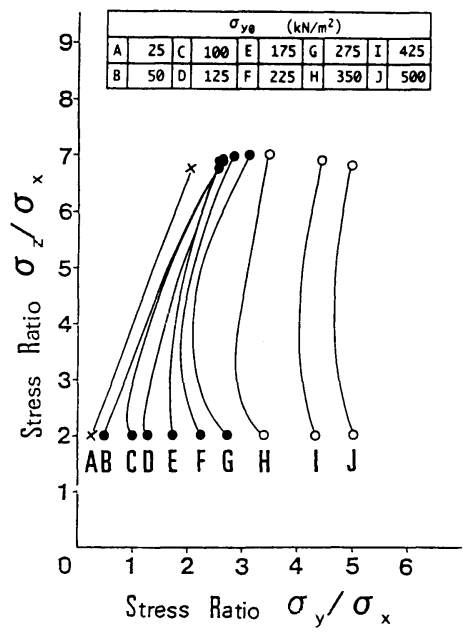

(2) $\sigma_{z 0}=200 \mathrm{kN} / \mathrm{m}^{2}$ の場合

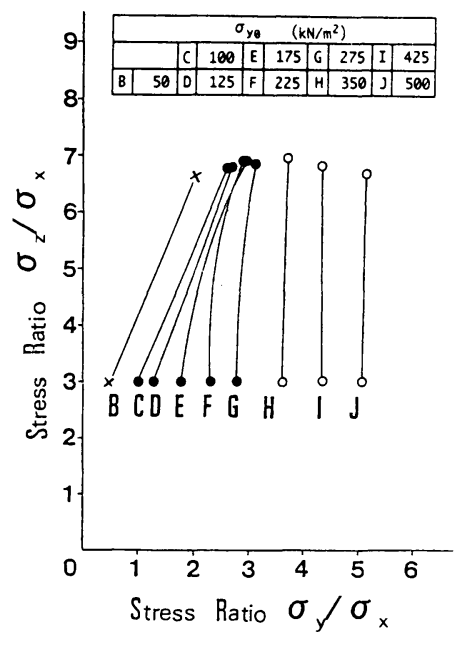

(3) $\sigma_{\% 0}=300 \mathrm{kN} / \mathrm{m}^{2}$ の場合

図-10 平面ひずみ圧縮過程の応力径路 $\left(\sigma_{y_{0} 0}\right.$ の影響, $\left.\sigma_{x}=\sigma_{x 0}=100 \mathrm{kN} / \mathrm{m}^{2}\right)$

C ((C)図) : Bのある状態から， $\sigma_{y}$ を一定にして, $\sigma$ 。增加していく，異方圧縮過程である．供試体 の体積変化は， $\sigma_{z}$ を増加すると，新たに収縮の変 化を示していく.

\section{C ）体積変化特性による分類}

図-8は, 各初期応力状態について, 上述の体積 変化特性に着目して分類したものである.この分類 は, 初期応力達成時の体積変化特性の状況が, 図一 9 のように，膨張に転ずることなく一貫して収縮し ていこうとする領域にある (contracting, 以下こ のような初期状態をこう呼ぶ）のか, または体積変 化が膨張に転じた領域にある (dilating, 以下この ような初期状態をこう呼ぶ）のかに着目して行った ものである. 図一 8より, 今回達成した初期応力状 態における体積変化状況は, 次のような 3 つのパター ンに分けられる.

I のパターン： 初期応力状態が, $\sigma_{y_{0}}<100$ $\mathrm{kN} / \mathrm{m}^{2}$ の場合で, 初期応力達成時の体積変化特性 が, $\sigma_{z}$ の単調載荷によりdilatingの状態にあるもの （X印）.

II のハターン： 初期応力達成時の体積変化特性が,

一貫して収縮を示すcontractingの状態にあるもの （○印）.

IIIパターン： 初期応力達成時の体積変化特性が, I のパターンとは異なって， $\sigma_{\mathrm{y}}$ の載荷により膨張 に転じたdilatingの状態にあるもの（○印）。この パターンのものは， $\sigma_{z}$ がさらに載荷された複合載 荷の状態のものが多いが, この場合体積変化はまた 収縮となる。

\section{（3）平面ひずみ圧縮過程}

初期応力の及ぼす平面ひずみ圧縮過程のせん断挙 動への影響を, 応力径路, 応力ひずみ関係, 強度の 順に述べる.

\section{a) 応力径路}

i ) 初期応力 $\sigma_{y 0}$ の影響 図-10は, 初期応力 $\sigma_{20}$ の大きさ別に, 平面ひずみ圧縮過程での応力径 路へ及ぼす $\sigma_{\mathrm{y} 0}$ の影響を示したものである. 図のメ，

○, ○印の応力経路は, 図-8（体積変化特性によ る分類図）に示した印と対応している.これより, 次の諸点が認められる.

（イ）応力径路は, 初期応力達成時の体積変化特性 から分けた 3 つのパターン I, II, 回に対応して区 分けできる。すなわち, (1)初期応力状態が contractingの状態にあるIのパターン（の印, $\left.\left(\sigma_{y} / \sigma_{x}\right)_{0} \geqq 0.5\right)$ の応力径路は, 破壊時の応力比 $\left(\sigma_{y} / \sigma_{x}\right){ }_{1}$ が2.5 3.1の範囲に収束していく傾向が ある. (2)初期応力状態がdilatingのもののうち, $\sigma_{z}$ の単調載荷によるI のパターン（X印, $\left(\sigma_{\mathrm{y}} / \sigma_{x}\right)_{0}$ $\leqq 0.5)$ の応力径路は, 破壊時の応力比 $\left(\sigma_{y} / \sigma_{x}\right)$ が, 上述の収束域より小さい側にずれる. (3)初期灾力状 態が, (2) と同様, dilatingのもののうち, $\sigma_{z}, \sigma_{y}$

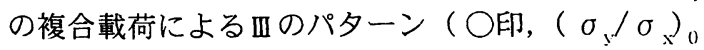
$\geqq 3.5 ）$ の応力径路は，破壊時の応力比 $\left(\sigma_{y} / \sigma_{x}\right)$ ， が， $\sigma_{\mathrm{y} 0}$ 載荷による誘導異方性により上述の(1)の収 束域より大きい側に゙あり, かつ, 初期応力状態の応 力比 $\left(\sigma_{\mathrm{y}} / \sigma_{\mathrm{x}}\right)_{0}$ とほぼ同じ值になっている.

（口）このような応力径路のパターン分けは，の初 期応力 $\sigma_{z 0}$ の值の場合にも, 同様に認められる. 


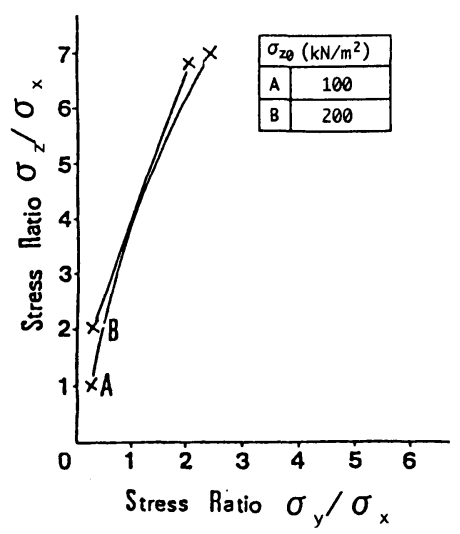

(1) $\sigma_{\mathrm{y} 0}=25 \mathrm{kN} / \mathrm{m}^{2}$ O場合

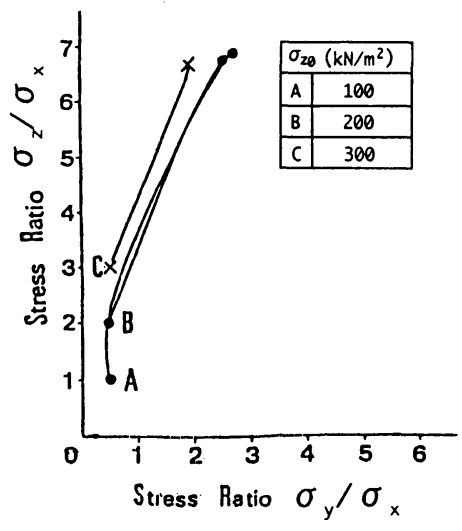

(2) $\sigma_{\text {y } 0}=50 \mathrm{kN} / \mathrm{m}^{2}$ の場合

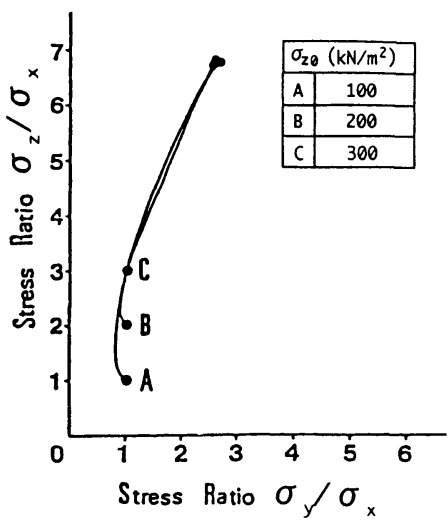

(3) $\sigma_{y 0}=100 \mathrm{kN} / \mathrm{m}^{2}$ の場合

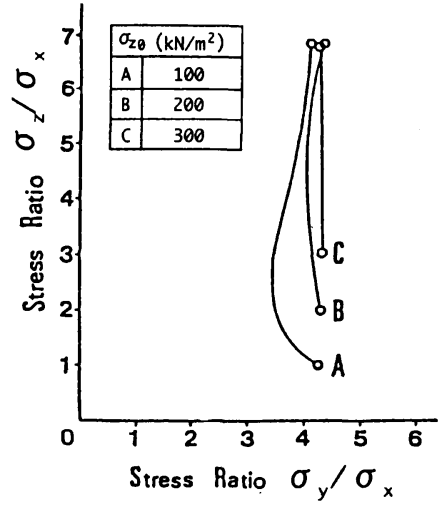

(4) $\sigma_{y()}=425 \mathrm{kN} / \mathrm{m}^{2}$ の場合

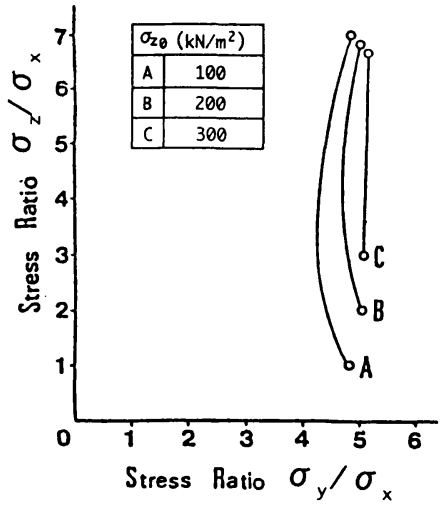

(5) $\sigma_{y(1)}=500 \mathrm{kN} / \mathrm{m}^{2}$ の場合

図-11 平面ひずみ圧縮過程の忘力径路 $\left(\sigma_{\%(0)}\right.$ の影響, $\left.\sigma_{\mathrm{x}}=\sigma_{\mathrm{x} 0}=100 \mathrm{kN} / \mathrm{m}^{2}\right)$

（ハ）破壊時の応力比 $\left(\sigma_{z} / \sigma_{x}\right)$, の大きさは, 初期 応力状態に無関係に、ほぼ同じ様な值になっている.

ii ）初期応力 $\sigma_{z 0}$ の影響図-11は, 前述の初 期応力状態の 3 つのパターンについて, $\sigma_{y(1)}$ の大き さ別に応力径路の代表例を示したものである. 図一 11 の応力径路に示してあるメ,

○、印は, 前述 と同様，それぞれ I， II， IIIのパターンに属してい ることを示している.すなおち図中の(1)図 $\left(\sigma_{y 0}=\right.$ $\left.25 \mathrm{kN} / \mathrm{m}^{2}\right)$ は I ( ×印)のパターン, (2)図 $\left(\sigma_{y 0}=\right.$ $\left.50 \mathrm{kN} / \mathrm{m}^{2}\right)$ は I $(\times)$ とII (の)のパターン, （3)図 $\left(\sigma_{\text {y } 0}=100 \mathrm{kN} / \mathrm{m}^{2}\right)$ は II (O)のパターン, (4)図 $\left(\sigma_{y_{0}}=425 \mathrm{kN} / \mathrm{m}^{2}\right)$ と $(5)$ 図 $\left(\sigma_{\text {y }_{0}}=500 \mathrm{kN} / \mathrm{m}^{2}\right)$ は四 (○)のパターンの応力径路を示したものである.こ れらの図より, 次の諸点が認められる.

(1) II，IIIのハターンの応力径路（(2)〜(5)図の○, ○印）は各図とも，破壊時の応力比 $\left(\sigma_{y} / \sigma_{x}\right)$ は $\sigma_{z 0}$ の大きさに関わらずそれぞれ同じ值に集まる.

(2)特に, IIIのパターンの応力径路 ((4)図,(5)図の○
印）は, 前項でも指摘したように, 破壊時の応力比 $\left(\sigma_{y} / \sigma_{x}\right){ }_{r}$ は $\sigma_{y} 0$ 載荷による誘導異方性の影響に より初期応力比 $\left(\sigma_{y} / \sigma_{x}\right)_{0}$ とほぼ同じになっている. (3)しかし，Iのパターンの応力径路（(1)図の×印） は, 初期応力 $\sigma_{y 0}$ が同じでも, 破壊時の応力比 $\left(\sigma_{\mathrm{y}} / \sigma_{\mathrm{x}}\right)_{\mathrm{f}}$ は異なり， $\sigma_{\mathrm{z}_{0}}$ が大きくなると小さく なる.また（2）図に示すように，初期応力 $\sigma_{{ }_{y} 0}$ が 同じである I (X印)と II (○印)のパターンを比べて も，I の破壊時の応力比 $\left(\sigma_{y} / \sigma_{x}\right)$ \& は II のれと比 べて, かなり小さくなっている.

このように, 応力径路については, 初期応力 $\sigma_{y 0}$ の影響は, 初期応力達成時の体積変化特性を考慮す ることにより，3つのパターンに対応して明確に把 握できる.しかしながら，初期応力 $\sigma_{z: 0}$ の影響につ いては, 今回の実験では $\sigma_{y_{0}}$ に比べ応力が小さく, また数も少ないためI のパターン(X印)を除き $\sigma 20$ の影響はあまり認められない. なお，これらの挙動 は 3.(1)でも述べているように，供試体の初期構造 


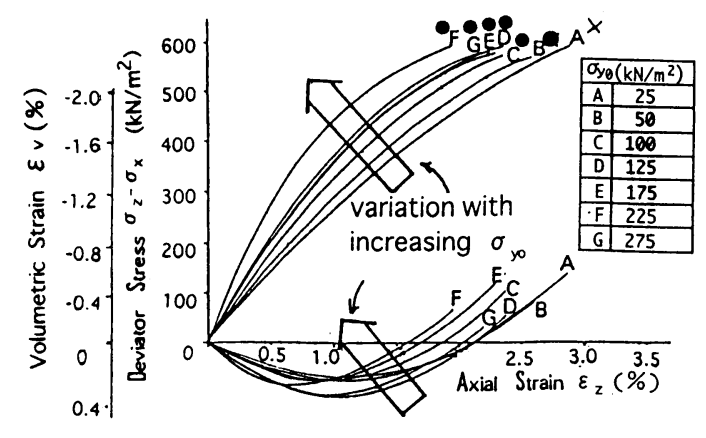

(i) $\sigma_{y_{0}} \leqq 275 \mathrm{kN} / \mathrm{m}^{2} \sigma$ 場合

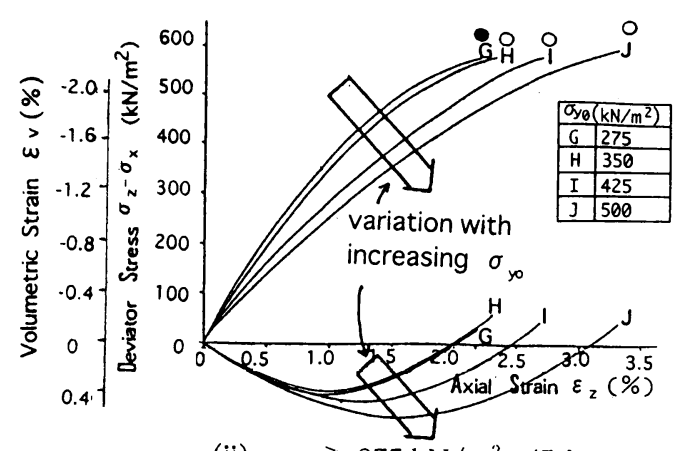

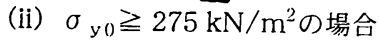

(1) $\sigma_{z_{0}}=100 \mathrm{kN} / \mathrm{m}^{2} 0$ ) 場含

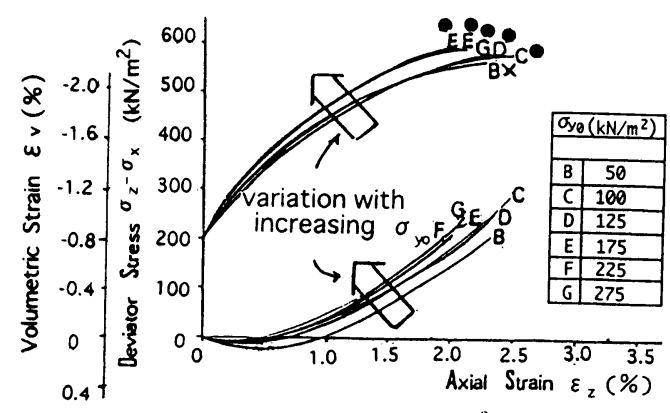

(i) $\sigma_{y_{0}} \leqq 275 \mathrm{kN} / \mathrm{m}^{2}$ の場合

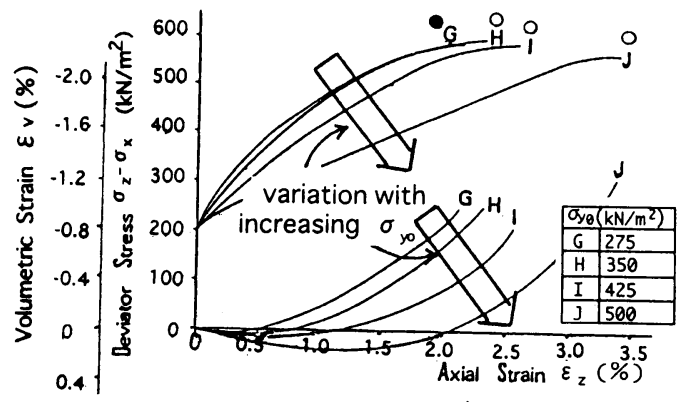

(ii) $\sigma_{y_{0}} \geqq 275 \mathrm{kN} / \dot{m}^{2}$ の場合

(2) $\sigma_{z_{0}}=300 \mathrm{kN} / \mathrm{m}^{2}$ 0)場合

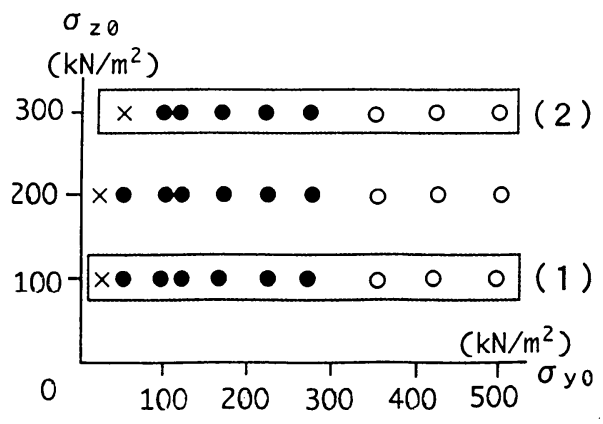

（3）初期応力状態

图-12 平面ひずみ圧絔過程の応力ひずみ関係 $\left(\sigma_{x 00}\right.$ の影響, $\left.\sigma_{x}=\sigma_{x 0}=100 \mathrm{kN} / \mathrm{m}^{2}\right)$

特性は等方的なので, すべて $\sigma_{y_{0}}$ および $\sigma_{z}$ 載荷 による誘導異方性により生じたものといえる.

\section{b ）応力ひずみ関係}

i ) 初期応力 $\sigma_{\text {y } 0}$ の影響 図-12 は, 応力ひず み関係に及ぼす初期応力 $\sigma_{y_{0}}$ の影響を， $\sigma_{20}$ が $100 \mathrm{kN} / \mathrm{m}^{2}$ ((1)図) の場合と $300 \mathrm{kN} / \mathrm{m}^{2}$ ((2)図) の場合について示したものである.（1)，(2)の各図 の(i)図，(ii)図は，それぞれ $\sigma_{y_{0}} \leqq 275 \mathrm{kN} / \mathrm{m}^{2}$ ， $\sigma_{y 0} \geqq 275 \mathrm{kN} / \mathrm{m}^{2}$ の場合の図である.また，(3)図 は(1)，(2)図に示したものの初期応力状態を示して いる. なお, 図中の記号 $\mathrm{A} \sim \mathrm{J}$ は, 図-10（応力 径路図， $\sigma_{y 0}$ の影響）と対芯しており，またメ， ○の印は，前述と同様そ扎ぞれ I， II，IIIのパター ンを示している.これらの図より次のことが認めら れる.

(1) $\sigma \%=100 \mathrm{kN} / \mathrm{m}^{2}$ ((1)図) の場合では, パターン 


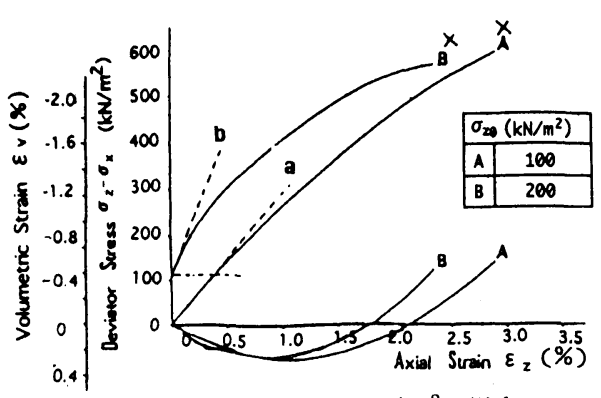

(1) $\sigma_{y 0}=25 \mathrm{kN} / \mathrm{m}^{2}$ の場合

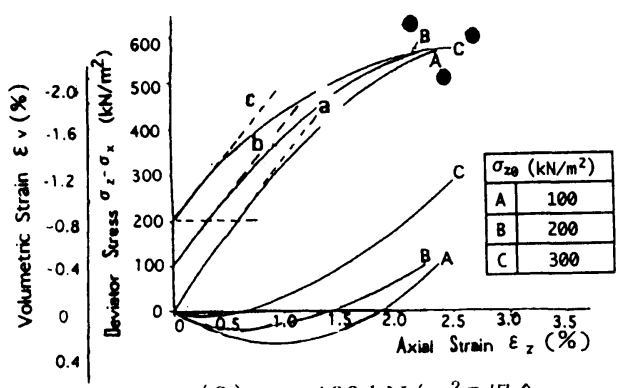

(3) $\sigma_{y(1)}=100 \mathrm{kN} / \mathrm{m}^{2}$ の場合

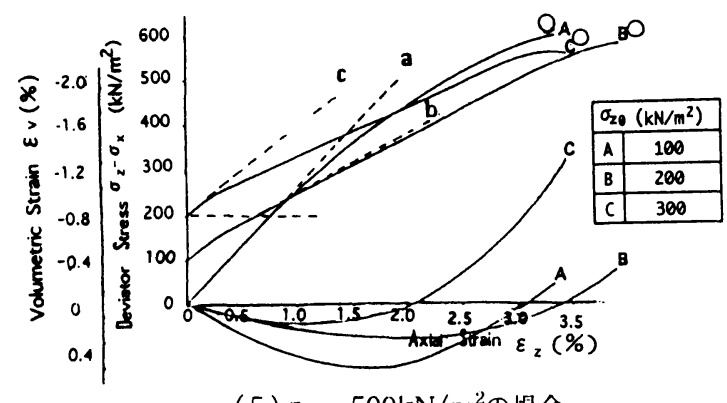

(5) $\sigma_{y(1)}=500 \mathrm{kN} / \mathrm{m}^{2}$ の場合

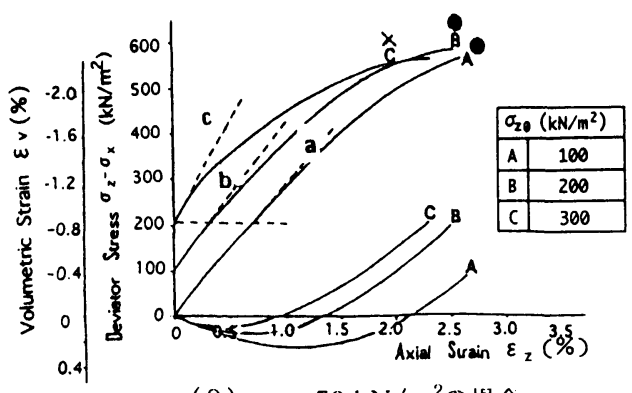

(2) $\sigma_{y 0}=50 \mathrm{kN} / \mathrm{m}^{2} 0$ ) 場合

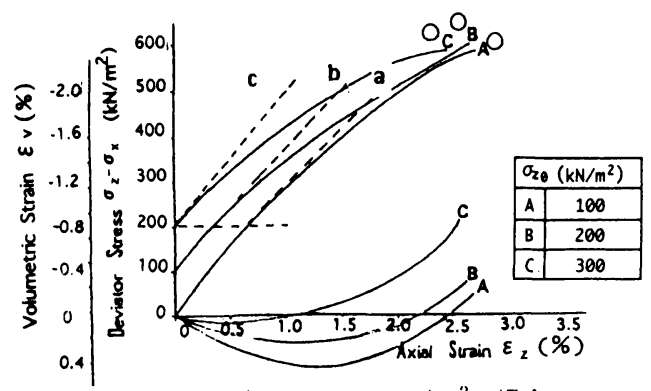

(4) $\left.\sigma_{y 11}=425 \mathrm{kN} / \mathrm{m}^{2} 0\right)$ 場台

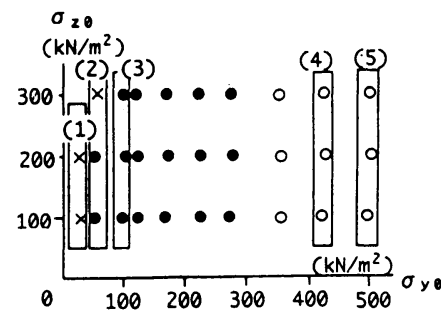

（6）初期応力状態

図-13 平面ひずみ圧縮過程の応力ひずみ関係 $\left(\sigma_{\% 0}\right.$ のの影響, $\left.\sigma_{x}=\sigma_{x 0}=100 \mathrm{kN} / \mathrm{m}^{2}\right)$

II （○印）の B Gの場合（(i)図），軸差応力一軸 ひずみ曲線はGを除いて全てが， $\sigma_{y_{0}}$ が大きくなる $(B \rightarrow G)$ につれて，矢印のように初期勾配が急に なり，また破壊時の軸ひずみ $\varepsilon_{z,}$ も小さくなり，剛 性が大きくなる $\left(\sigma_{z 0}=200 \mathrm{kN} / \mathrm{m}^{2}\right.$ の場合の図は掲 載していないが, この場合は，FとGの逆転はな い). しかし, パターンIII（O印）の $\mathrm{H} \sim \mathrm{J}$ の場合 ((ii)図) では，逆に， $\sigma_{y_{0}}$ が大きくなる $(\mathrm{H} \rightarrow \mathrm{J})$ につれて, 軸差応力ー軸ひずみ曲線の初期勾配はゆ るくなり, また破壊時の軸ひずみ $\varepsilon_{z i}$ も大きくなり, 剛性が小さくなる，なお，(i)図のA（×印， $\sigma_{y 0}=$ $25 \mathrm{kN} / \mathrm{m}^{2}$ ) の I のパターンは, 1 つしかないので $\sigma_{\mathrm{y} 0}$ の影響は分からないが，IIのパターン（の印） の端に位置している.

(2) $\sigma_{z 0}=300 \mathrm{kN} / \mathrm{m}^{2}$ ((2)図) の場合になると，(i)図
に示すパターンＩ（○）のC～Gの場合では，上記 の(1)図の(i)図と同様の傾向がみられるが，変化の 幅が小さくなり，まとまっている. (ii)図に示すパ夕ンIII（O）のH〜 J の場合では，変化幅は変わらず, 上記の（1）図の(ii)図の場合と同様， $\sigma_{y 0}$ が大きく なると延性的になる.

(3)体積変化特性については, 多少のばらつきはある が，基本的に上述と同様の傾向が認められる，すな わち，(1)図(2)図とも（i)図に示すように，（品/ $\left.\sigma_{\mathrm{x}}\right)_{0}<3.5$ の場合（II のパターン）では， $\sigma_{\mathrm{y}, 0}$ が大 きくなるに従って, 矢印のように体積の収縮量が小 さくなる傾向があるが，この変化の幅は， $\sigma_{20}$ が $300 \mathrm{kN} / \mathrm{m}^{2}$ と大きくなると小さくなり，まとまって くる. また, (ii)図に示す $\left(\sigma_{y} / \sigma_{x}\right)_{0} \geqq 3.5$ の場合（III のパターン）では，(i)図の場合とは逆に， $\sigma_{y 01}$ が大 
きくなるに従って，体積の収縮量が大きくなる傾向 がある，但し， なっても, この変化の幅は変わらない.

ii ) 初期応力 $\sigma_{20}$ の影響 図-13の(1) (5)図 は，応力ひずみ関係に及ぼす $\sigma \% 0$ の影響を，前掲の 図-11 (応力径路図, $\sigma_{z_{0}}$ の影響)に対忘させて, $\sigma_{y_{0}}$ の大きさ別に示したものである. また図には, 軸差応力ー軸ひずみ曲線の初期接線勾配 ( $a, b, c)$ も 書き入れてある。なお，(6)図は，(1)〜 (5)図の場合 の初期応力状態を示したものである.これより次の ことが認められる.

(1)どの図の場合も, 若干のばらつきはあるが，巨視 的な傾向は等しい。つまり，軸差応力一軸ひずみ曲 線は， $\sigma_{z 0}$ の相違に関係なく破壊付近で同じような 軸ひずみに集まり，体積変化特性は， $\sigma_{70}$ の増加に つれて膨張側に移動する傾向となる.

(2)しかし， $\left(\sigma_{z}-\sigma_{x}\right)$ が同じレベル（点線 ， $\sigma_{z}$ $\left.\sigma_{\mathrm{x}}=100,200 \mathrm{kN} / \mathrm{m}^{2}\right)$ の軸差応力ー軸ひずみ曲線 の接線勾配に着目すると，(1)図の軸差忘力ー軸ひず み曲線（Iのパターン, ×印）は $\sigma \%$ の増加によっ て剛性が高くなり，また，(2)図のC（Iのパター ン, ×印）もの \%が小さいA， B（IIのパターン，

○印）に比べると剛性が高くなっている。しかし， (5)図 $\left(\sigma_{y(1)}=500 \mathrm{kN} / \mathrm{m}^{2}\right)$ のように破壊状態に近い IIIのパターンは $\sigma ， 0$ の増加によって逆に剛性が低下 する傾向がみられる. その他の場合については, 時 別な傾向は認められない.

このように, 応力ひずみ関係については, 初期応 力 $\sigma_{y 0}$ の影響は, 初期応力達成時の体積变化特性に 着目した II, IIIの 2 つのパターンに対応して分類で きる. しかし, 初期応力 $\sigma_{z 0}$ の影響については, 破

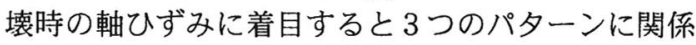
なくほぼ 1 つしして見ることができる，但し，Iの パターンについてはデータ数が少ない.

なお, 前述 ( a)応力経路) のように, 本供試体 の初期構造特性は等方的なので, これらの挙動は全 て初期応力 $\sigma_{y_{0}}$ および $\sigma_{z 0}$ 載荷による誘導異方性 に起因しているわけであるが，しかしながら，これ らの誘導異方性により生じた平面ひずみ挙動と初期 応力状態との具体的な関連性については, 現時点で はまだ述べるに至っていない.

\section{c）せん断強さ}

i）破壊状況 まず, 供試体の破壊状況について 述べる. 写真- 2 は, 試験終了後, 更に圧縮してす ベり面の状況をはっきりさせた供試体を， $\sigma_{\mathrm{y}}$ 方向 （拘束板方向）から示したものである. 今回実施し た供試体は，いずれもこのようにすべり面はV字型 に入った.これは, どの供試体も $\sigma_{z P}>\sigma_{y P}>\sigma_{x i}$ と

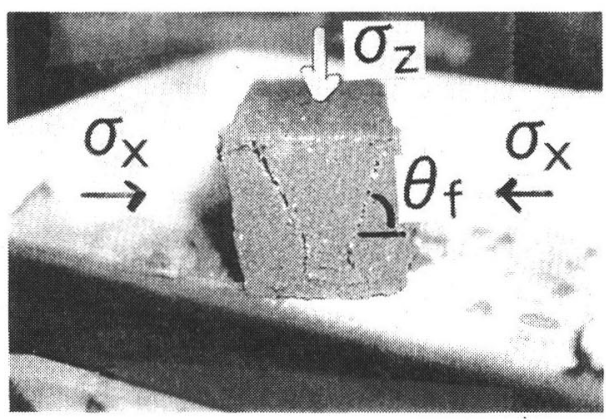

写真- 2 供試体の破壊状湜

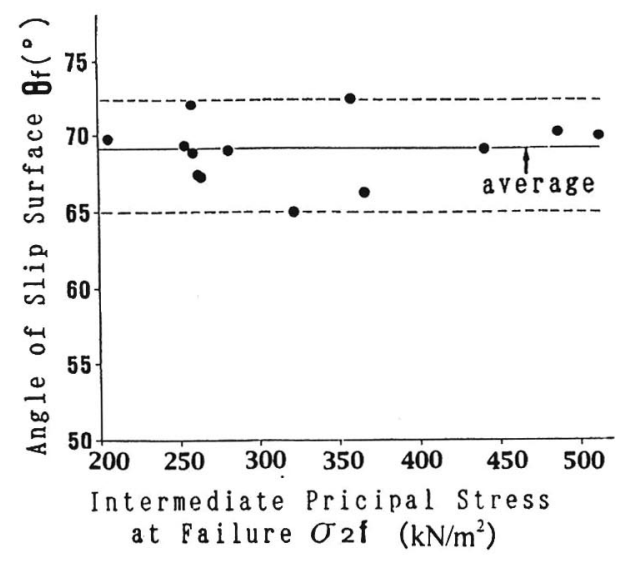

図-14 すべり面角度と破壊時の中間主応力の関係

いう関係にあるため, 最小主応力の $\sigma_{\mathrm{x}}$ 方向に粒子 がずれやすくなったからである. また,このすべり 面が単一すべり面でないのは, 本実験の供試体の幅 (w)に対して高さ(h)があまり高くないことに起因し ているものである. なお, このすべり面の角度 $\theta$, (平均 $\left.\theta, \fallingdotseq 69^{\circ}\right)$ と, 破壊時の中間主応力 $\sigma_{2 \mathrm{f}}(=$ $\left.\sigma_{y}\right)$ の関係を見ると, 図-14のようになり, すべ り面角度 $\theta$,に $\sigma_{2 \mathrm{f}}$ の影響は認められないことがわ かる. また，このすべり面角度から内部摩擦角を求 めると $\phi=2 \theta_{1}-(\pi / 2)=48^{\circ}$ となり, これは次節 で述べている内部摩擦角 $47.2^{\circ} \sim 49.1^{\circ}$ の中間の值 となっている.

ii）せん断強さと間げき比図-10の応力径路 でも述べたが，各応力径路の終点の值 $\left(\sigma_{\%} / \sigma_{x}\right)$ ， は，ほぼ同じような值になり，せん断強度には初期 応力状態の影響は見受けられなかった。ここでは， 間げき比の違いを考慮にいれて，せん断強さをより 詳細に検討してみる.なお, 間げき比は, 初期応力 の載荷によって0.01〜0.02ほど微小ではあるが変化 するので, 初期応力達成時の間げき比 $\mathrm{e}_{\mathrm{c}}$ を用いて 検討した. 


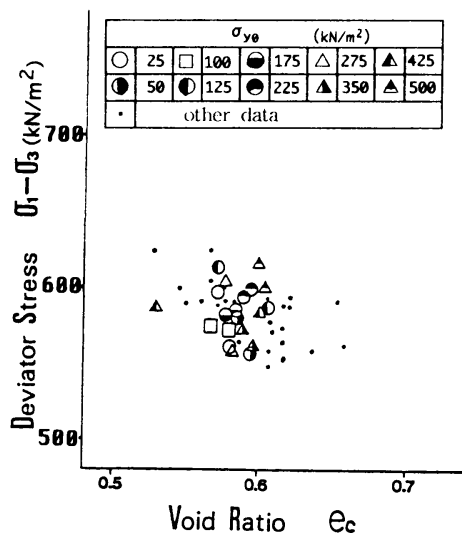

(1) $\sigma_{\%(0)}=100 \mathrm{kN} / \mathrm{m}^{2}$ の場合

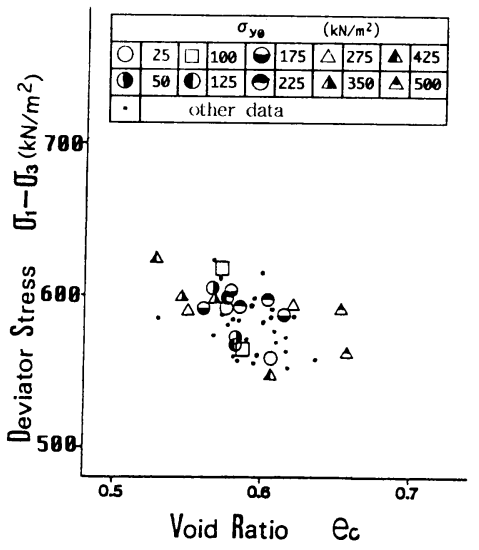

(2) $\sigma_{z 0}=200 \mathrm{kN} / \mathrm{m}^{2}$ の場合

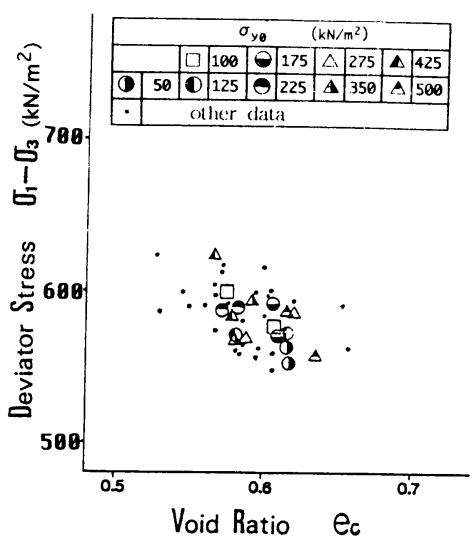

(3) $\sigma_{z 0}=300 \mathrm{kN} / \mathrm{m}^{2}$ の場合

図-15 せん断強さと間隙比（初期応力迮成時）の関係

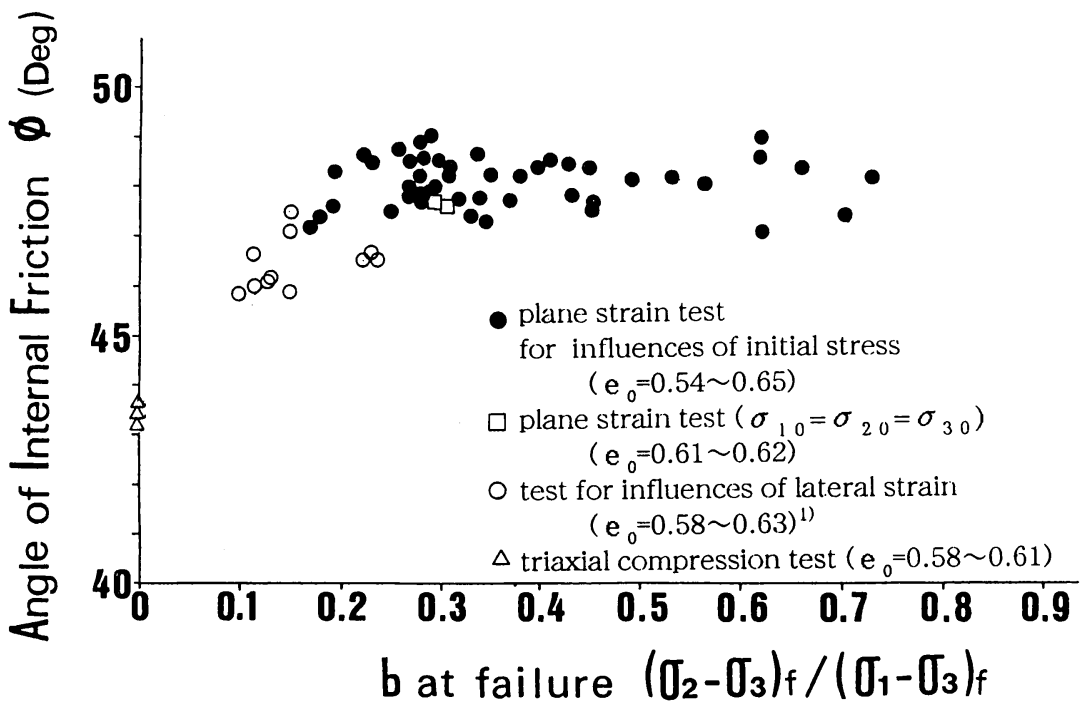

図-16 内部摩擦角と $\mathrm{b}$ 值の関係

図-15に，初期応力達成時の間げき比 $\mathrm{e}_{\mathrm{c}}$ とせん 断強さ $\left(\sigma_{1}-\sigma_{3}\right),\left(=\left(\sigma_{2}-\sigma_{2}\right)_{\mathrm{f}}\right)$ の関係を示す. (1) 図は $\sigma_{z 0}=100 \mathrm{kN} / \mathrm{m}^{2}, \quad$ (2) 図は $\sigma_{z 0}=200$ $\mathrm{kN} / \mathrm{m}^{2}$, (3) 図は $\sigma_{z 0}=300 \mathrm{kN} / \mathrm{m}^{2}$ のものであり, 各図の中の・归は, その図で取り上げた以外のデー 夕を示している。これらより, e cは0.53〜0.66, $\left(\sigma_{1}-\sigma_{3}\right)_{\mathrm{f}}$ は550 $620 \mathrm{kN} / \mathrm{m}^{2}$ (内部摩擦角 $\phi=$ $\sin ^{-1}\left[\left(\sigma_{1}-\sigma_{3}\right) /\left(\sigma_{1}+\sigma_{3}\right)\right]$ でいうと $47.2^{\circ} \sim 49.1$ 。）の範囲に分布しており, ばらつきはあるが全体 的に右下がりで， e cが大きいほどせん断強さは小 さくなるという一般的な傾向を示している.このよ うな状況を考慮すると, 初期応力状態の影響はせん 断強度には認められない。 すまわち, 誘導異方性の
影響は強度には認められない。

iii）内部摩擦角と $b$ 值の関係 図-16 は, 内部 摩擦角之b 値 $\left(\left(\sigma_{2}-\sigma_{3}\right)_{\mathrm{f}} /\left(\sigma_{1}-\sigma_{3}\right)_{\mathrm{f}}=\left(\sigma_{\mathrm{y}}-\sigma_{\mathrm{x}}\right)\right.$, $\left./\left(\sigma_{z}-\sigma_{x}\right)_{\mathrm{f}}\right)$ の関係を示したものである.なお

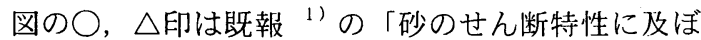
す側方拘束ひずみの影響」での結果を示している.

これより次の諸点が認められる.

(1)初期応力の影響を調べた本研究の実験結果（印） は, b 值が0.16〜0.73と広範囲に渡っている.

(2)初期応力を様々に変えた場合の内部摩擦角は，ば らついてはいるものの，等方状態の結果（口印）と 同じかそれより若干大きい範囲に分布（ $\phi=47.2$ $\left.49.1^{\circ}\right)$ しており，b值の影響は認められない。な お，このような傾向は山田 ${ }^{17)}$ のまとめたものによ 
表- 2 平面ひずみ挙動に及ぼす初期応力の影響

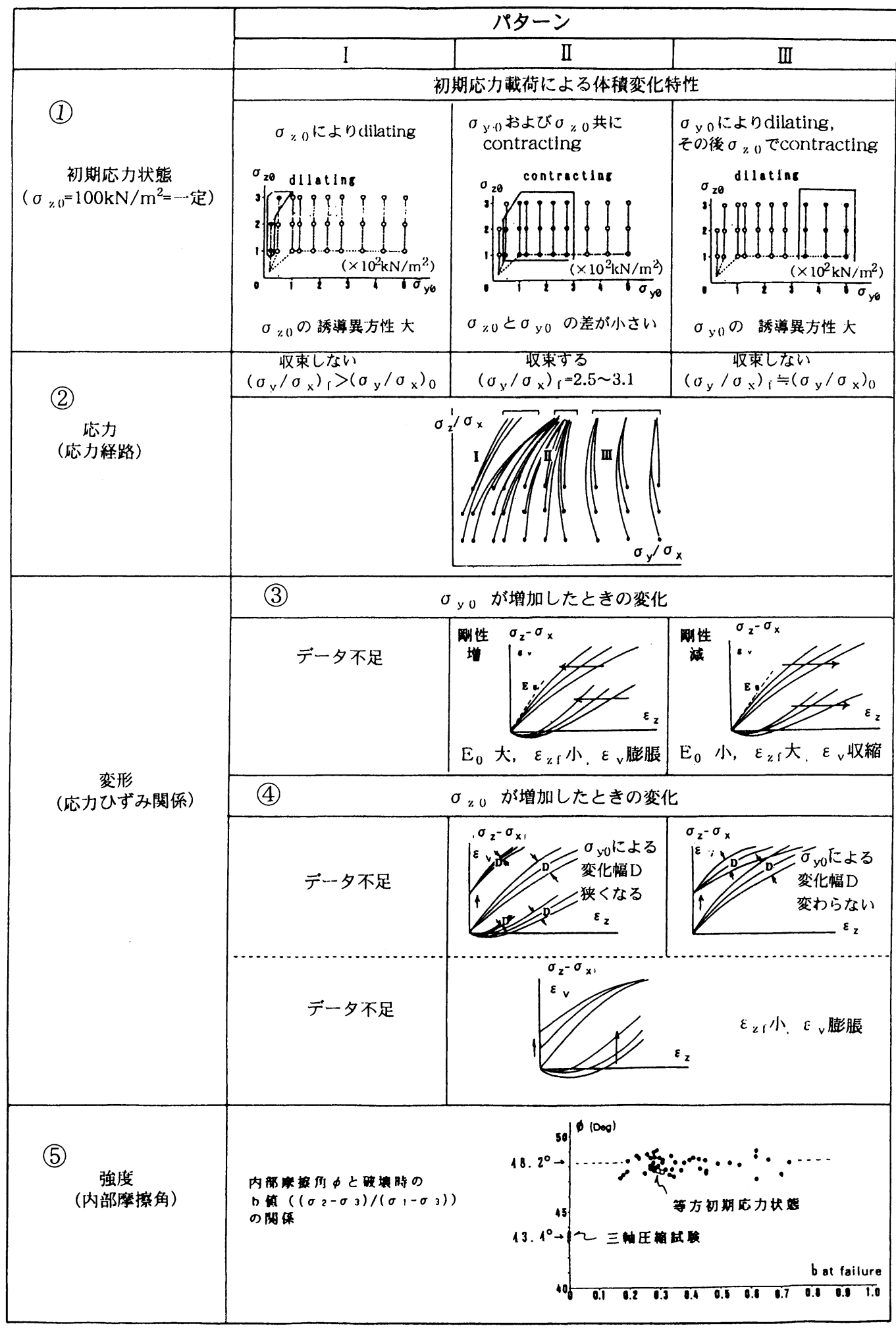


ると, 河上ら(1975), Ladeら(1973), Proctorら (1969)の実験にも見られる.

(3)また，既報 1)の側方ひずみの影響を調べた試験 結果（○印）活，b值が小さくなって抢り，そ扎に 伴って内部摩擦角も若干小さくなっている（ $\phi=$ 45.8〜 47. $6^{\circ}$ ). しかしながら,この $\phi$ の低下は $b=$ $0 の$ 三軸状態（ $\triangle$ 印， $\phi \fallingdotseq 43.4^{\circ} ）$ に比べ完全な平 面ひずみ試験（口印）に近い値となっている。

なお、図-16において，(2)で述べたように等方 初期応力状態の $\phi$ ( $\square$ 印) が, 他のもの（の印）の 分布の下限に位置している.これは, 初期応力详成 時の間隙比が等方初期応力状態の場合 $\mathrm{e}_{\mathrm{c}}=0.60$ 〜 0.61 となっているのに対して, 周辺に分布している $\mathrm{b}$ 值が0.26 0.37（初期応力達成時の体積変化特性 はcontractingの状態）のデータの 7 割近くが $e_{\mathrm{c}}=$ 0.55〜0.59と小さい間隙比になっているため, この 違いによるものと考えられる.

\section{4. 結論}

今回実施した平面ひずみ挙動へ及ぼす初期応力状 態の影響を調べる実験から得られた結果をまとめる と表-2のようになる.なお，表中の(1)〜(5)の番号 は, 以下の結果に示した番号と対応している.

(1)初期応力状態: 初期応力達成時における体積变化 特性の状態, つまり体積が収縮していこうとする

（contracting）状態にあるのか，またはその体積 変化が膨張に転じた（dilating）状態にあるのかに 着目することによって, 初期応力状態を図のように I , II , IIIの 3 つのパターンに分けることができる.

(2)応力（応力経路）: 平面ひずみ圧縮試験の応力径 路は, このような初期応力状態のパターンに対応し て図に示すように 3 つに分類できる。すすおち, contractingの状態にあるII のパターンのものは, 圧縮が進むにつれて破壊時の応力比 $\left(\sigma_{y} / \sigma_{x}\right)$, (= $\left.\left(\sigma_{2} / \sigma_{3}\right)_{1}\right)$ はある領域 $(2.5 \sim 3.1)$ に収束してい こうとする. しかしながら, dilatingの状態にある もののうち側方の初期応力 $\sigma_{y 0}$ が小さい I のパター ンのものは, $\left(\sigma_{\mathrm{y}} / \sigma_{\mathrm{x}}\right)_{\mathrm{f}}$ は収束せず上記の領域より 小さくなり， $\sigma_{y 0}$ が大きい四のパターンの場合は, $\left(\sigma_{y} / \sigma_{x}\right)_{p} \fallingdotseq\left(\sigma_{y} / \sigma_{x}\right)_{0}$ となる.このように dilatingの状態にあるI のパターンは $\sigma_{z 0}$ 載荷によ る誘導異方性が大きく, IIIのパターンは $\sigma_{y_{0}}$ 載荷に よる誘導異方性が大きい.

(3)変形（応力ひずみ関係， $\sigma_{\text {yo }}$ 増加の影響）：応力 径路と同じように, 初期応力状態のパターン分けに 対応した影響が現れ, 初期応力の載荷による誘導異
方性の影響を区分けできる. 側方の初期応力 $\sigma_{y 0}$ の 変化に対して見てみると, II のパターンのものは,

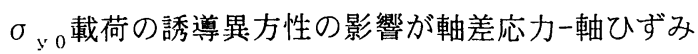
曲線の初期接線勾配 $\mathrm{E}_{0}$ の增加之破壊時の軸ひずみ $\varepsilon_{7 \mathrm{f}}\left(=\varepsilon_{1 \mathrm{f}}\right)$ の減少をまねき, 供試体の風性を高め る. また, 体積変化については膨張側の発生を促す. しかし，IIIのパターンの場合は， $\sigma_{\mathrm{y} 0}$ 載荷の誘導異 方性の影響が全く逆の傾向をまねき，供試体の剛性 を減少させ，収縮側の体積変化を促す．なお，Iの パターンについてはデータ不足で言及できない.

(4)変形（応力ひずみ関係， $\sigma_{20}$ 増加の影響）：初期 応力 $\sigma_{20}$ の影響については, $\sigma_{20}$ が増加すると, パターンのII とIIIで, 側方の初期応 $\sigma_{\mathrm{y} 0}$ の変化に 対する応力ひずみ関係の変化幅が異なってくる. つ

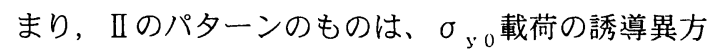
性の影響が， $\sigma_{20}$ が増加することにより打ち消され， $\sigma_{y 0}$ の変化による応力ひずみ関係の変化幅が非常に 狭くなる．しかし，IIIのパターンのものは， $\sigma_{\mathrm{y} 0}$ 載 荷の誘導異方性の影響が大きく， $\sigma_{20}$ の増加によっ て影響を受けないので, 変化幅は変わらない.

また，破壊時の軸ひずみ $\varepsilon_{2 \mathrm{f}}\left(=\varepsilon_{1 \mathrm{f}}\right)$ と体積変化 については，I のパターンはデータ不足で言及でき ないが， II， IIIのパターンでは共通して $\sigma_{z, 0}$ の増加 によって ${ }_{z}{ }_{1}$ はほぼ同じ所に収束していき, 体積変 化は膨張側に生じる傾向を示す。

(5)強度（内部摩擦角）：今回設定した初期応力条件 下での平面ひずみ状態の $\mathrm{b}$ 值は， $0.2 \sim 0.7$ 広い範 囲に分布しているが, 内部摩擦角の違いは見られず, 誘導異方性の影響を受けない.

\section{5.おわりに}

本研究をまとめるに当たり，有益なアドバイスを 下さった東京大学龍岡文夫教授, また実験を実施し てくれた卒研生の美野島央伸, 李保, 本多稳之君ら に感謝するとともに, 試験機の作製・改良に協力し てくれた東京試機工業株式会社の橋本正夫氏に感謝 いたします。

\section{参考文献}

1）徳江俊秀, 梅津喜美夫, 長谷川浩久; 砂のせん断特 性に及ぼす側方拘束ひずみの影響, 土木学会論文集, No.454/III-20,pp.65 74, 1992. 9.

2) Henkel,D.J. and Wade,N.H. : "Plane strain tests on a saturated remolded clay", ASCE, Vol.92, SM6, pp.67-80,1966. 
3) Nagaraj, T. S. and Somashekar, B.V. : "Stress deformation and strength of soils in plane strain", Proc. ARC(Asian Resional Conforence) on SMFE, Vol.1, pp.43-46,1979.

4) Marachi,N.Dean, Duncan,J.M., Chan,C.K. and Seed,H.B.: "Plane-strain testing of sand", Laboratory Shear Strength of Soil, ASTM STP740, R.N. Yong and F.C. Townsend, Eds., American Society for Testing and Materials (ASTM), 1981, pp.294-302,1981.

5）市原松平，松沢宏：「平面ひずみ状態と軸対 称ひずみ状態における乾燥砂のせ儿断特性」土木学会 論 文報告集，第173号，1970年1月．

6) Green,G.E. and Reades,D.W.: "Boundary conditions, anisotropy and sample shape effects on the stress-strain behaviour of sand in triaxial compression and plane strain", Geotechnique 25, No.2, pp.333-356,1975.

7) Tatsuoka,F., Sakamoto,M., Kawamura,T. and Fukushima,S.: "Strength and deformation characteristics of sand in plane straincompression at extremely low pressures", Soils and Foundations, Vol.26, No.1, pp.65-84,1986.

8）下辺 悟:「砂の三軸・平面ひずみ挙動」日本大学博士 論文, 1980 .

9）望月美登志，福島伸二：「標準試験としての大 型三軸・平面ひずみ圧縮試験の適用性」三軸試験方法 に関するシンポジウム発表論文集, 土質工学会, pp.181-186,1991.

10) Cornforth,D.H.: "Some experiments on the influence of strain conditions on the strength of sand", Geotechnique, Vol.14, No.2, pp.143167,1964 .

11) Finn,W.D.Liam, Wade,N.H. and Lee,Kenneth L. : "Volume Changes in Triaxial and Plane Strain Tests", Journal of the Soil Mechanics and Foundations Division, ASCE, Vol.93, No.SM6, Proc. Paper 5611, November 1967, pp.297-309,1967.

12) Barden,L., Ismail,H. and Tong,P.: "Plane Strain Deformation of Granular Material at Low and High Pressures", Geotechnique 19, No.4, pp.441-452,1969.

13) Lee,K.L.: "Comparison of plane strain and triaxial testson sands", J.Soil Mech. Fdns. Div. Proc. ASCE, Vol.96, No.SM3,pp.901-923,1970.

14) Vaid,Y.P. and Campanella,R.G.: "Triaxial and plane strain behaviour of natural clay", Proc. ASCE, Vol.100, GT3, pp.207-224,1974.

15) Oda , M. , Koishikawa , I. and Higuchi , T. "Experimental study of aniso- tropic shear strength of sand by plane strain test", Soils and Foundations, Vol.18, No.1, pp.25-38,1978.

16) Mitachi,T. and Kitago,S.: "Undrained triaxial and plane strain behaviour of saturated remolded clay", Soils and Foundations, Vol.20, No.1, pp.13-28,1980.

17）土質工学会:ロックフィル材料の試験と設計強度, pp.18-19, 1982.

(1998. 3. 26 受付)

\section{INFLUENCES OF INITIAL STRESS CONDITIONS ON PLANE STRAIN BEHAVIORS OF SAND SPECIMENS}

Toshihide TOKUE, Toshitaka KAMAI and Kimio UMETSU

Plane strain compression tests (CD-test, $\sigma_{x}=\sigma_{x 0}=$ const.) were performed on Toyoura sand specimens measuring $9 \times 8 \times 5 \mathrm{~cm}$. The initial stress conditions of these specimens varied within the range of $100 \leqq$ $\sigma_{(1)} \leqq 300,25 \leqq \sigma_{y 0} \leqq 500$ and $\sigma_{\mathrm{x} 0}=100\left(\mathrm{kN} / \mathrm{m}^{2}\right.$ - unit $)$. The following results were obtained:

(1) The initial stress conditions are divided into three groups according to the specimens' dilatancy during initial stress loading; (2) Stress paths and stress strain relations under plane strain compression are classified into two or three groups corresponding to these groups; (3) Strength parameter is unique irrespective of the initial stress conditions. 